\section{Ledelse av lærings- og mestringsaktiviteter}

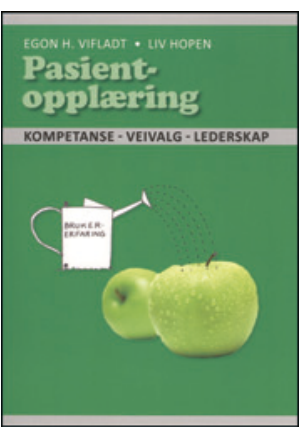

Egon H. Vifladt, Liv Hopen

Pasientopplæring

Kompetanse - veivalg - lederskap. 280 s,

ill. Oslo: Kolofon Forlag, 2013. Pris NOK 300 ISBN 978-82-300-1016-7

Dette er den andre boken fra Vifladt og Hopen om pasientopplæring. Den første kom i 2004 og het Helsepedagogikk - Samhandling om laering og mestring. Denne gangen er søkelyset rettet mot lederskap.

Boken kan ses på som en lære- og inspirasjonsbok for ledere som skal lede arbeidet med å gi et tilbud som bidrar til læring og mestring, spesielt for personer med langvarig sykdom og funksjonssvikt. Forfatterne gir en innføring i sentrale prinsipper for pasientopplæring med vekt på gruppebasert opplæring, hvordan slikt arbeid kan planlegges, ledes, gjennomføres og evalueres, i tillegg til ansvar og rolle for ledere på ulike nivåer i dette arbeidet. Et hovedbudskap er å trekke inn brukernes erfaringer aktivt og på den måten løfte frem hverdagserfaringer som avgjørende kunnskap. Dette gjenspeiler det som har vært sentralt i oppbyggingen av lærings- og mestringsaktiviteter i Norge, det å likestille brukererfaring og fagkunnskap i arbeidet med pasientopplæring («standard metode» for de innvidde).

Søkelyset på lederskap begrunnes med at det er en lederoppgave å sørge for at pasientopplæring er en integrert del av den behandlingen og pleien som tilbys i spesialist- og kommunehelsetjenesten. Pasient- og pårørendeopplæring er en av de fire lovpålagte oppgavene for helseforetakene, men er både som fagfelt og praksis fortsatt i stor grad en attpåklatt. Derfor er mye av boken viet hvordan slikt arbeid kan gjøres i praksis, og viktigheten av å sikre at det systematisk skjer en utvikling av kompetanse mellom helsevesen og brukere.

Det mest karakteristiske er den utstrakte bruken av sitater i teksten. Boken er ellers rikt krydret med dikt, små tegninger av blomster og spørsmål til ettertanke. Den språklige stilen er kort og kjapp. Forfatterne legger stor vekt å skape refleksjon hos leseren og bruker på den måten noen av de sentrale prinsippene i helsepedagogikken i kommunikasjonen med leserne. Fordi det er en noe uvant form kan det virke fremmed, men gitt budskapet tror jeg de fleste lesere vil finne dette berikende.

Denne boken er et godt bidrag for ledere på ulike nivåer som har et ansvar for pasientopplæringen, enten for å sette det i gang, integrere det i pasientbehandlingen eller for å få inspirasjon til å videreutvikle dagens aktiviteter. Og ett av de siste sitatene, fra Søren Kierkegaard (1813-1855), belyser både hensikt, læring og mestringstiltak: «Det er jeg og ingen annen som må treffe avgjørelser, med tanke på hvordan jeg skal takle det inntrufne.»

\section{Aslak Steinsbekk}

Professor, Institutt for samfunnsmedisin

Norges teknisk-naturvitenskapelige universitet

\section{Velger unge et mer ansvarlig drikkemønster?}

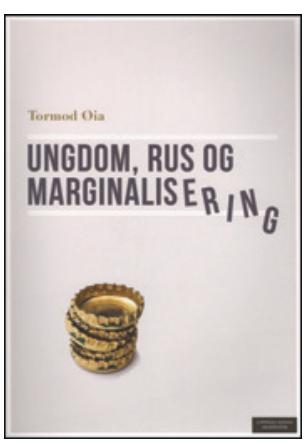

Tormod Øia

Ungdom, rus og marginalisering

248 s, tab, ill. Oslo: Cappelen Damm

Akademisk, 2013. Pris NOK 369

ISBN 978-82-02-43198-3

Hvorfor drikker ungdom? Spørsmålet innleder den sist utkomne boken til Tormod Øia. Den tar utgangspunkt i Ung i Oslo-undersøkelsen 2012. Undersøkelsen er en oppfølging av tilsvarende undersøkelser utført i Oslo i 1996 og 2006. Et gjennomgående spørsmål til deltakerne er: «Hvor ofte har du drukket deg tydelig beruset det siste året?» Funnene blir belyst ut fra ulike teorier for å forstå unges alkoholbruk. Befolkningen over 15 år har siden krigen økt sitt årlige forbruk med fire liter ren sprit. Mens foreldregenerasjonen øker sitt alkoholforbruk, er trenden motsatt for ungdom. I 1996 hadde $54 \%$ av de unge drukket seg tydelig beruset det siste året, mot $37 \%$ i 2012.

I de første kapitlene går forfatteren gjennom norske alkoholtradisjoner, unges alkoholforbruk i dag og deres sårbarhet i forhold til alkohol. Han gjennomgår sammenhenger mellom alkoholbruk, marginalisering og utstøting.

De resterende kapitlene er viet resultater fra undersøkelsene: dagens drikkemønster blant unge i Oslo, sammenhengene mellom foreldrenes atferd, økonomi og utdanning og unges drikkemønster, betydningen av venner, skole, jevnaldermiljø og virkningene av å delta i fritidsaktiviteter. Øia ser på bruk av alkohol hos ungdom i sin alminnelighet og hos ungdom som kommer i drift. Han setter søkelys på mulig innflytelse fra livsstil, kultur, subkultur, psykisk helse og religion.

Flere av funnene overrasker meg. Et eksempel er aldersgruppens $\mathrm{u}$-formede kurve for sosioøkonomisk drikkemønster: Barna til de fattigste og rikeste foreldrene drikker mest. Det er tankevekkende at unge som trener i idrettslag, drikker mindre enn gjennomsnittet, mens unge som trener på helsestudio, drikker mer. Mindre overraskende er det at unge i familier der den gjensidige tilliten er frynsete, drikker mer enn andre unge. Og at de unge som drikker minst, har størst tillit til institusjonene i samfunnet. Troen på en gud er også forbundet med lavere alkoholforbruk.

Rapportformen kan virke litt repeterende og tørr, men et godt språk og relevante og velfunderte drøftinger av funnene oppveier for dette.

Bredden av temaer gjør boken interessant for alle som i sitt arbeid har med ungdom å gjøre. Den er i tillegg aktuell for foreldre og fritidsledere, ikke minst i idretten.

At trendene for bruk av alkohol i voksenkulturen og ungdomskulturen går hver sin vei, forteller om underliggende strømninger i samfunnet. Øia klarer med denne boken å peke på noen av disse.

Ole Rikard Haavet

Førsteamanuensis, Avdeling for allmennmedisin

Universitetet i Oslo 